Uniwersytet Przyrodniczo-

Humanistyczny w Siedlcach

Siedlce University of Natural

Sciences and Humanities

https://bazawiedzy.uph.edu.pl

\begin{tabular}{|l|l|}
\hline Publikacja / Publication & $\begin{array}{l}\text { Number and size of nucleoli in the spermatocytes of chicken and Japanese quail, } \\
\text { Andraszek Katarzyna, Gryzińska Magdalena, Knaga Sebastian Jakub, Wójcik Ewa } \\
\text { Agnieszka, Smalec Elżbieta Maria }\end{array}$ \\
\hline $\begin{array}{l}\text { Adres publikacji w Repozytorium } \\
\text { URL / Publication address in } \\
\text { Repository }\end{array}$ & https://bazawiedzy.uph.edu.pl/info/article/UPH7144b0c4e68e4212b5023112e6f33753/ \\
\hline $\begin{array}{l}\text { Data opublikowania w Repozytorium } \\
\text { / Deposited in Repository on }\end{array}$ & 22 paź 2021 \\
\hline Rodzaj licencji / Type of licence & Other open licence \& \\
\hline & $\begin{array}{l}\text { Andraszek Katarzyna, Gryzińska Magdalena, Knaga Sebastian Jakub, Wójcik Ewa } \\
\text { Agnieszka, Smalec Elżbieta Maria: Number and size of nucleoli in the spermatocytes } \\
\text { of chicken and Japanese quail, Folia Biologica-Krakow, vol. 60, no. 3, 2012, pp. 121- } \\
127\end{array}$ \\
\hline
\end{tabular}




\title{
Number and Size of Nucleoli in the Spermatocytes of Chicken and Japanese Quail
}

\author{
Katarzyna ANDRASZEK, Magdalena GRYZIŃSKA, Sebastian KNAGA, Ewa WÓJCIK \\ and Elżbieta SMALEC
}

Accepted May 22, 2012

\begin{abstract}
ANDRASZEK K., GryZiŃSKA M., KNAGA S., WóJCik E., SMALeC E. 2012. Number and size of nucleoli in the spermatocytes of chicken and Japanese quail. Folia Biologica (Kraków) 60: $121-127$

Nucleoli are the product of nucleolus organizing region activity (NOR) of specific chromosomes. Their basic function is to synthetise ribosomal RNA precursors and promote the maturation and assemblage of preribosomal RNP molecules. Information on rRNA-coding gene activity can be provided by the analysis of the number and size of nucleoli in the prophase of the first meiotic division. The morphology and ultrastructure of a nucleolus depends, among others, on the species and cell growth cycle as well as the physiological and pathological state of an organism. The purpose of this research was to determine the number and size of nucleoli in the spermatocytes of the domestic chicken and the Japanese quail. Diverse numbers and sizes of nucleoli in the cells of the analysed birds were observed. 1-4 nucleoli were identified in chicken cells $(1.91 \pm 0.63$ on average) and $1-2$ in quail cells $(1.13 \pm 0.33$ on average $)$. For the total of 957 nucleoli observed in Gallus cells, 329 were classified as large and 628 as small. In Coturnix cells, 563 nucleoli were identified (66 large and 497 small ones). An analysis of the numbers and sizes of nucleoli can be performed at the cytogenetic level and serve as an alternative source of information on rRNA encoding gene and nucleolus organising region (NOR) activities.

Key words: Meiotic chromosomes, spermatogenesis, nucleoli, Gallus gallus domesticus, Coturnix coturnix japonica.

Katarzyna ANDRASZEK, Ewa WÓJCIK, Elżbieta SMALEC, Institute of Bioengineering and Animal Breeding, Siedlce University of Natural Sciences and Humanities, Prusa 14, 08-110 Siedlce, Poland.

E-mail: andrasz@uph.edu.pl

Magdalena GRYZINSSKA, Sebastian KNAGA, Department of Biological Basis of Animal Production, University of Life Sciences, Akademicka 13, 20-950 Lublin, Poland.
\end{abstract}

The nucleolus is the largest and best known functional constituent of the cell nucleus. It is formed by original products of ribosomal RNA genes contained in the nucleolar organiser, related proteins and various enzymes, including RNA polymerase, RNA methylase and RNA endonuclease (OLSON et al. 2002; HERNANDEZ-VERDUN 2006). The nucleolus is the site of synthesis and maturation of ribosomal RNA (rRNA) molecules. The molecules also bond with proteins in the nucleolus. rRNA genes are situated in particular chromosomes, in nucleolar organizer regions (NORs) that participate in the formation of nucleoli (DEREZINI et al. 2005; LAM et al. 2005; PRIETO \& MCSTAY 2005). Nucleoli are present in the nuclei of almost all eukaryotic cells since they contain elementary metabolic genes, with the exception of spermatozoa and mature avian erythrocytes (RAŠKA et al. 2004, 2006).

The weight of nucleoli is higher than that of the nucleoplasm in which the nucleoli are suspended.
On account of its distinctive density, compact structure and low water content (10\%) the nucleolus is an organelle that can be readily distinguished. Due to its characteristics, following cell nucleus fragmentation, the nucleolus remains intact in a saline solution even after the destruction of most nuclear structures, thereby allowing its isolation through centrifugation. The isolated nucleolus is identical to the one present in the nucleus of a living cell, and even retains its transcriptional activity in some cases (OLSON 2002; HERNANDEZ-VERDUN 2006; RAŠKA et al. 2006).

The number of nucleoli in a cell nucleus is determined by the number of active nucleolar organiser regions (NORs). It may be equal to the number of those NOR-chromosomes. Yet, normally, it is lower. This can be explained either by the fusion of nucleoli in the interphase nucleus or the suppression of activity of certain rDNA loci (OLSON et al. 2002; RAŠKA et al. 2006). 
The size of nucleoli in vertebrates ranges from 5 to $10 \mu \mathrm{m}$. It varies depending on the cellular demand for ribosomes. Cells which do not intensively synthesise proteins, e.g. skeletal muscle cells, have small nucleoli, whereas e.g. liver cells, which are characterised by an elevated level of protein synthesis, have larger nucleoli (SHAW \& JORDAN 1995). Nucleolar morphology and ultrastructure varies according to the species, cell type, differentiation degree and cell cycle. Young cells have smooth nucleoli. As the body grows older, the shape of the nucleolus becomes irregular. The nucleolus also changes in response to various physiological and pathological conditions (RAŠKA et al. 2004; LAM et al. 2005; ANDRASZEK et al. 2010).

Both nucleoli and nucleolar organiser regions have chemical affinity for heavy metals and can be identified through staining with silver nitrate in a protective colloidal solution of formalin or gelatine (HOWELL \& BLACK 1980). Silver staining induces the appearance of yellow-brown chromosomes with black silver deposits corresponding to the location of nucleolar organiser regions or the appearance of dark chromatin-bound nucleoli. The silver staining technique is a popular method for detecting specific acidic, strongly argentophile and non-histone protein complexes associated with rRNA genes. These proteins have been designated as Ag-NOR, due to their affinity for $\mathrm{Ag}+$ ions and their temporary association with NORs in chromosomes. AgNOR proteins include: nucleolin, B23 protein, class I RNA polymerase subunits and UBF (upstream binding factor). UBF is a binding agent for an rRNA promotor. It facilitates the commencement of rDNA transcription (OLSON et al. 2002; OSPINA \& MATERA 2002; RAŠKA et al. 2004).

Since nucleolar organiser regions (NORs) determine the structure of nucleoli, an alternative source of information on the activity of avian rRNA-encoding genes can be found by an analysis of the numbers and sizes of nucleoli in the prophase of the first meiotic division. Throughout the prophase, nucleoli are not degraded. As opposed to mitotic NORs, they are large structures (ANDRASZEK \& SMALEC 2007; ANDRASZEK et al.2009a; ANDRASZEK et al.2010).

Gallus gallus domesticus is a model organism for application in biomedical and evolutionary assays, as well as in comparative genomics. The karyotype of Gallus domesticus is the only standardised pattern of avian chromosomes which serves as a point of reference in research on other bird species (LADJALI-MOHAMMEDI et al. 1999; SCHMID et al. 2000, 2005; GUTTENBACH et al. 2003) and mammals (BURT et al. 1999). Moreover, the genome of Gallus domesticus is the only mapped avian genome. It is regarded as a model in comparative genomics (ICGSC 2004; MASABANDA 2004). Coturnix coturnix japonica is also more and more often used as a model organism for experiments. However, a high diploid number and the presence of microchromosomes in the avian karyotype considerably limit the possibilities of cytogenetic analyses.

Meiotic chromosomes, which are unfortunately only sporadically used in cytodiagnostics, provide valuable information on bird karyotypes (ANDRASZEK \& SMALEC 2007; ANDRASZEK \& SMALEC 2008; ANDRASZEK et al. 2008; ANDRASZEK et al. 2009a, b).

The purpose of the present study was to analyse the number and sizes of nucleoli in spermatocytes of Gallus gallus domesticus and Coturnix coturnix japonica.

\section{Material and Methods}

The study was carried out according to the guidelines of the III Ethical Committee in Warszawa (No. 36/2011 and No 37/2011 from the 22 June 2011).

Meiotic chromosomes were isolated from the testes of 30-week-old Japanese quail (Coturnix japonica) males and 64-week-old Polbar (Gallus domesticus) males. Each species was represented by 10 birds. The animals came from terminated flocks that belonged to the Department of Biological Basis of Animal Production at University of Life Sciences in Lublin. Birds of both species were still in the reproductive age. Meiotic chromosomes were isolated using the POLLOCK \& FECHHEIMER method (1978). The nucleoli were identified using the method of nucleolar organiser region staining in mitotic chromosomes (HOWELL \& BLACK 1980). A $50 \% \mathrm{AgNO}_{3}$ solution and a colloidal gelatine solution were applied on the 1-week-old preparations. The preparations were covered with a cover glass and incubated for $15-20$ minutes at $60^{\circ} \mathrm{C}$, in complete humidity. After the preparations turned brown in colour, the chemical reaction was interrupted and the preparations were rinsed several times with distilled water.

Ready preparations were analysed with an OLYMPUS BX 50 microscope, using the Multiscan system. For each animal, 50 plates with chromosomes in the first stage of the meiotic prophase were analysed. The number and size of nucleoli in the cell were identified and the mean and standard error calculated.

\section{Results}

Silver nitrate staining enabled the identification of nucleoli in both bird species that constituted the experimental material. The presence of nucleoli 
was unambiguously identified, regardless of the prophase stage or staining intensity. The surface of individual nucleoli was not measured because the cells collected for analysis from each bird were typical of different stages of prophase of the first meiotic division. Nucleoli in early prophase were larger than the nucleoli in subsequent stages of prophase and if they had been classified as small in the cells at the beginning of prophase, in the cells in subsequent prophase stages they would have been classified as large. However, both large and small nucleoli were always observed in the analysed cells, regardless of the prophase stage.

Analysis of the number and sizes of nucleoli in Coturnix cells

Variable numbers of nucleoli were observed both in particular animals and among birds. In particular individuals, the number of nucleoli ranged from 1 to 2 (Fig. 1) -1.13 per cell, on average. For the total of 500 analysed cells, 437 had one nucleolus, while in 63 there were two nucleoli.

The analysis also involved the determination of the sizes of nucleoli in particular cells. In each animal different nucleolar sizes were observed. The nucleoli were classified as large or small (Fig. 2). Small nucleoli predominated in the cells of each male. For the total of 563 nucleoli, 66 were classified as large and 497 as small. Detailed results of the analysis of the numbers and sizes of nucleoli in Coturnix cells are presented in Table 1.

Analysis of the number and sizes of nucleoli in Gallus cells

Variable numbers of nucleoli were observed in the cells of the cocks. Variability was observed both in the cells of particular birds and among individuals. In particular birds, the number of nucleoli ranged from 1 to 4 (Fig. 3) - 1.91 per cell, on average. For the total of 500 cells, 114 cells were found to have one nucleolus, 322 - two nucleoli, 57 three and 7 - four. Gallus cells were also analysed for the sizes of the nucleoli which were classified as large or small (Fig. 4). For the total of 957 nucleoli, 329 were classified as large and the remaining 628 as small. Detailed results of the analysis of the numbers and sizes of nucleoli in Gallus cells are presented in Table 2 .

\section{Discussion}

Different numbers and sizes of nucleoli can be identified in the cells of the same animal. Such variability can also be species-specific. In the experiments performed as part of the present study of quail, 1-2 nucleoli were observed, whereas 1-4 nucleoli were found in the chicken cells. In both species the nucleoli varied in size. This variability is assumed to stem from the species-specific number of nucleolar organiser regions and the activity of rRNA-encoding genes.

The number of nucleoli in a well-formed nucleus is equal to or lower than the number of NORs, due to the fusion of adjacent nucleoli (RAŠKA et al. 2006) or the association of satellite chromosomes with an active NOR (ANDRASZEK et al. 2009a). Moreover, genes located in different NORchromosomes participate in the formation of one nucleolus. This was confirmed in studies of other animal species. In cattle and goats, the NOR number attains a maximum of 10 (DI BERARDINO et al. 2001). The numbers of nucleoli in spermatocytes are as follows: 1 in cattle (ANDRASZEK \& SMALEC 2011 - unpublished results) and 2 in goats (out of which one is always more prominently stained) (ANDRASZEK et al. 2009a). The number of active NORs in horses is at most 6 (BowLING et al. 1997) and these animals have one nucleolus (ANDRASZEK et al. 2010). The domestic goose has maximally four nucleolar organising regions (APITZ et al. 1995), while the number of nucleoli ranges from 1 to 4 . The nucleoli are of different size (ANDRASZEK \& SMALEC 2007).

According to other sources, the quail karyotype has maximally four active nucleolar organiser regions connected with one pair of macro- and one pair of microchromosomes (MC NALLY 2004), whereas maximally two active nucleolar organiser regions have been identified in the hen karyotype (SCHMID et al. 2005; DELANY et al. 2009).

The results of the present research show that the maximum number of nucleoli in quail and chicken is 2 and 4, respectively. In the case of quail, the rule saying that the number of nucleoli is equal to or lower than the number of active NORs was confirmed. On the other hand, the number of nucleoli in the chicken cells exceeded the number of active NORs identified for Gallus domesticus. The reason for this difference may be trisomy in chickens - associated with the 16th pair of chromosomes in this case. More than two nucleoli were also observed in chicken cells by Muscarella et al. (1985) and DELANY et al. (1991). The authors confirmed that a higher number of nucleoli may result from the presence of trisomic or tetrasomic nuclei in the cells of the analysed birds.

The variability in the number and sizes of nucleoli in a cell, both individually and species-specifically, are undoubtedly influenced by changes in the activity of the nucleolar organiser regions.

Cytogenetic research conducted as part of projects intended to standardise the karyotypes of vari- 

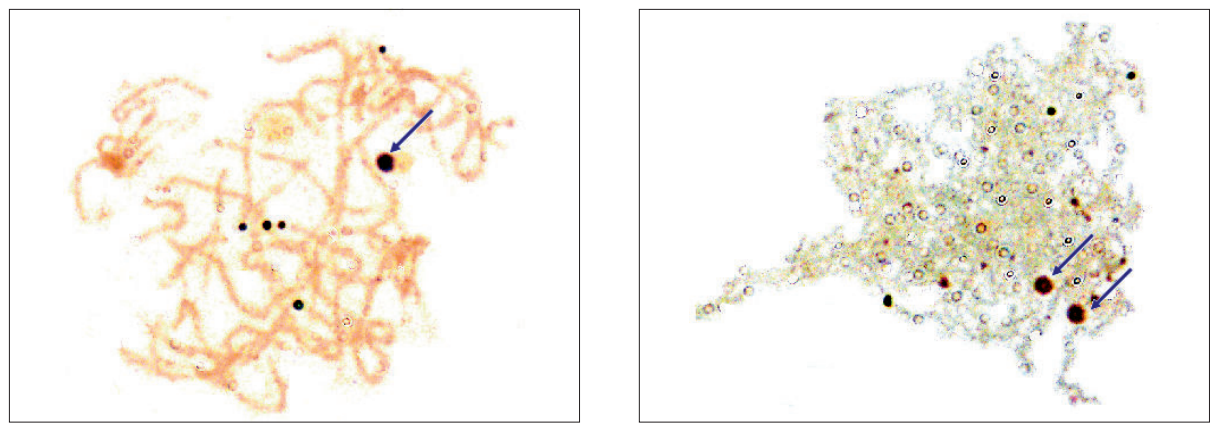

Fig. 1. Variability of the number of nucleoli in Coturnix cells. The nucleoli are indicated with arrows.
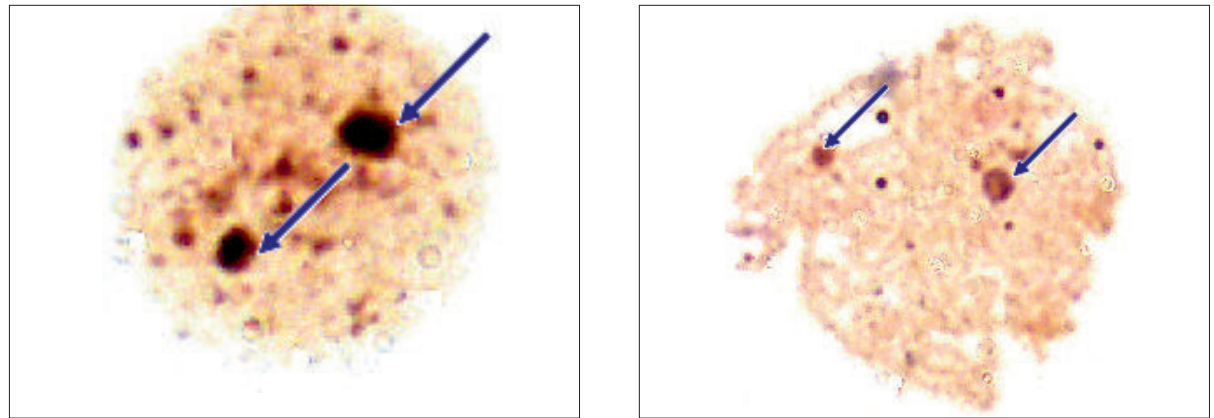

Fig. 2. Variability of the sizes of nucleoli in Coturnix cells. The nucleoli are indicated with arrows.
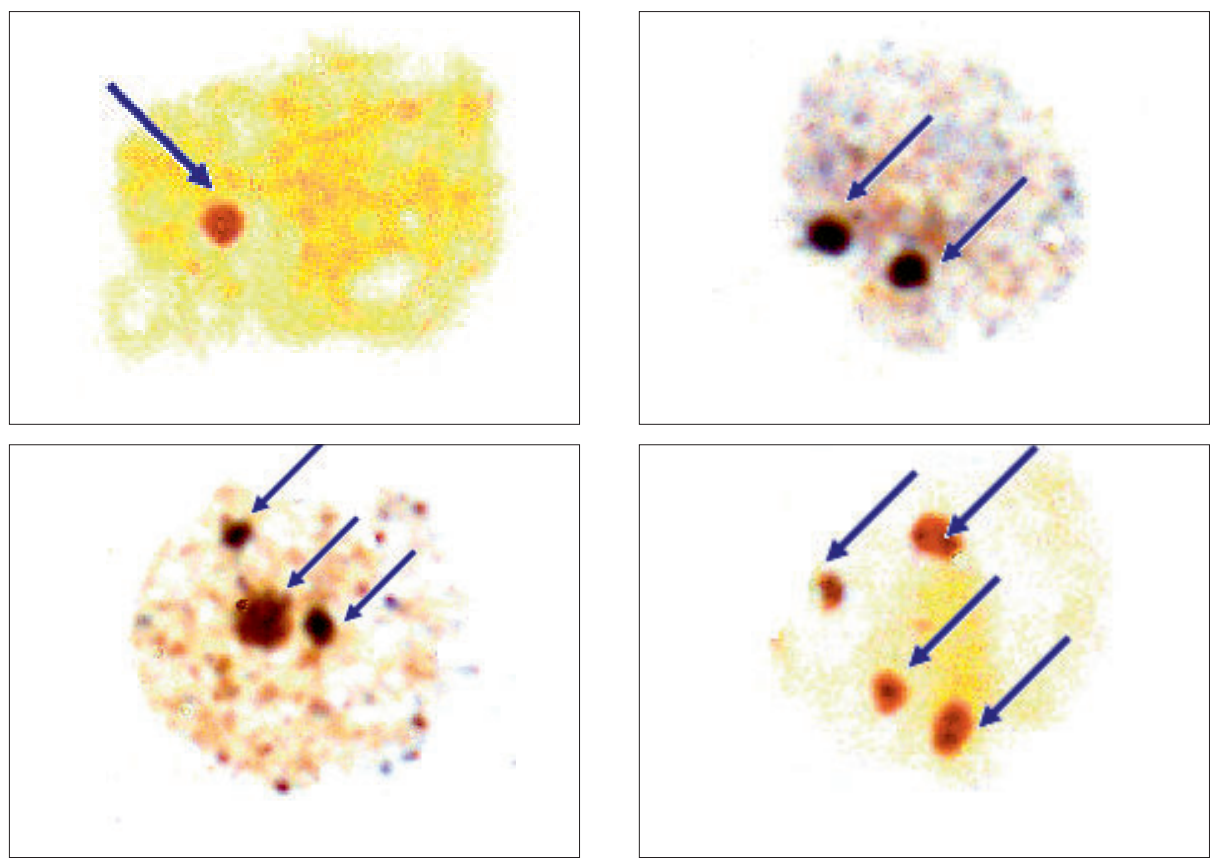

Fig. 3. Variability of the number of nucleoli in Gallus cells. The nucleoli are indicated with arrows.
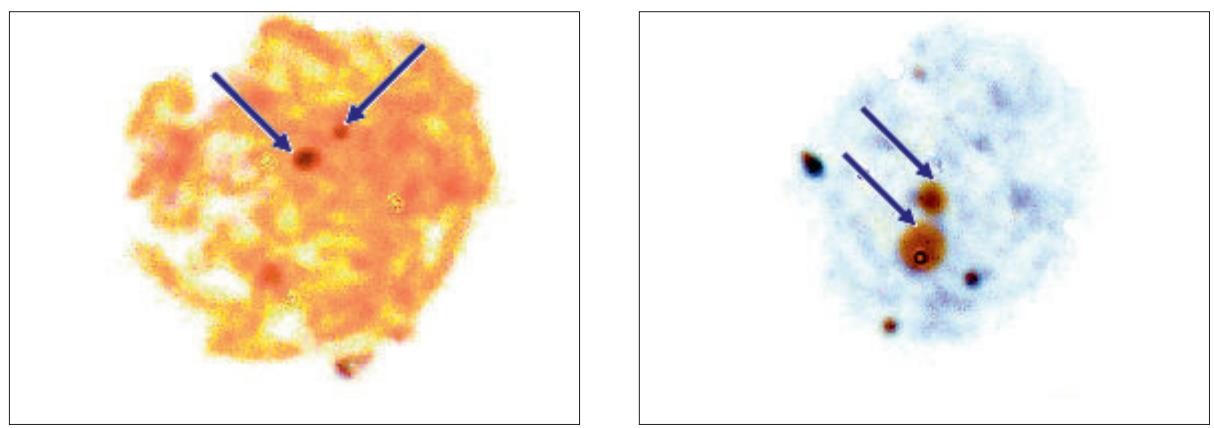

Fig. 4. Variability of the sizes of nucleoli in Gallus cells. The nucleoli are indicated with arrows. 
Table 1

Results of the analysis of nucleolar numbers and sizes in Coturnix cells

\begin{tabular}{|c|c|c|c|c|c|c|c|}
\hline \multirow[t]{2}{*}{ Animal } & \multirow[t]{2}{*}{$\begin{array}{l}\text { Number } \\
\text { of cell }\end{array}$} & \multicolumn{2}{|c|}{$\begin{array}{l}\text { Number of cells } \\
\text { with a particular quantity } \\
\text { of nucleoli }\end{array}$} & \multirow[t]{2}{*}{$\begin{array}{l}\text { Number } \\
\text { of nucleoli }\end{array}$} & \multirow{2}{*}{$\begin{array}{l}\text { Number } \\
\text { of nucleoli } \\
\text { per cell } \\
\overline{\mathrm{X}} \pm \mathrm{SD}\end{array}$} & \multicolumn{2}{|c|}{$\begin{array}{l}\text { Size of nucleoli } \\
\text { in the cells }\end{array}$} \\
\hline & & 1 & 2 & & & large & small \\
\hline 1 & 50 & 48 & 2 & 52 & $1.04 \pm 0.20$ & 9 & 43 \\
\hline 2 & 50 & 46 & 4 & 54 & $1.08 \pm 0.27$ & 6 & 48 \\
\hline 3 & 50 & 46 & 4 & 54 & $1.08 \pm 0.27$ & 9 & 45 \\
\hline 4 & 50 & 46 & 4 & 54 & $1.08 \pm 0.27$ & 8 & 46 \\
\hline 5 & 50 & 36 & 14 & 64 & $1.28 \pm 0.45$ & 8 & 56 \\
\hline 6 & 50 & 46 & 4 & 54 & $1.08 \pm 0.27$ & 4 & 50 \\
\hline 7 & 50 & 46 & 4 & 54 & $1.08 \pm 0.27$ & 5 & 49 \\
\hline 8 & 50 & 42 & 8 & 58 & $1.16 \pm 0.37$ & 6 & 52 \\
\hline 9 & 50 & 41 & 9 & 59 & $1.18 \pm 0.39$ & 6 & 53 \\
\hline 10 & 50 & 40 & 10 & 60 & $1.20 \pm 0.40$ & 5 & 55 \\
\hline Total & 500 & $\begin{array}{c}437 \\
(88 \%) \\
\end{array}$ & $\begin{array}{c}63 \\
(12 \%) \\
\end{array}$ & 563 & $1.13 \pm 0.33$ & $\begin{array}{c}66 \\
(12 \%) \\
\end{array}$ & $\begin{array}{c}497 \\
(88 \%) \\
\end{array}$ \\
\hline
\end{tabular}

Table 2

Results of the analysis of nucleolar numbers and sizes in Gallus cells

\begin{tabular}{|c|c|c|c|c|c|c|c|c|c|}
\hline \multirow{2}{*}{ Animal } & \multirow{2}{*}{$\begin{array}{c}\text { Number } \\
\text { of cell }\end{array}$} & \multicolumn{4}{|c|}{$\begin{array}{l}\text { Number of cells } \\
\text { with a particular quantity of nucleoli }\end{array}$} & \multirow{2}{*}{$\begin{array}{l}\text { Number } \\
\text { of nucleoli }\end{array}$} & \multirow{2}{*}{$\begin{array}{l}\text { Number } \\
\text { of nucleoli } \\
\text { per cell } \\
\overline{\mathrm{X}} \pm \mathrm{SD}\end{array}$} & \multicolumn{2}{|c|}{$\begin{array}{l}\text { Size of nucleoli } \\
\text { in the cells }\end{array}$} \\
\hline & & 1 & 2 & 3 & 4 & & & large & small \\
\hline 1 & 50 & 13 & 35 & 2 & - & 89 & $1.78 \pm 0.51$ & 25 & 64 \\
\hline 2 & 50 & 9 & 31 & 9 & 1 & 102 & $1.55 \pm 0.67$ & 28 & 74 \\
\hline 3 & 50 & 7 & 39 & 3 & 1 & 98 & $1.96 \pm 0.53$ & 41 & 57 \\
\hline 4 & 50 & 12 & 31 & 5 & 2 & 97 & $1.94 \pm 0.71$ & 22 & 75 \\
\hline 5 & 50 & 8 & 34 & 6 & 2 & 102 & $2.04 \pm 0.67$ & 44 & 58 \\
\hline 6 & 50 & 7 & 27 & 15 & 1 & 110 & $2.20 \pm 0.70$ & 49 & 61 \\
\hline 7 & 50 & 12 & 34 & 4 & - & 92 & $1.84 \pm 0.55$ & 34 & 58 \\
\hline 8 & 50 & 20 & 26 & 4 & - & 84 & $1.68 \pm 0.62$ & 23 & 61 \\
\hline 9 & 50 & 13 & 34 & 3 & - & 90 & $1.80 \pm 0.53$ & 31 & 59 \\
\hline 10 & 50 & 13 & 31 & 6 & - & 93 & $1.86 \pm 0.61$ & 32 & 61 \\
\hline Total & 500 & $\begin{array}{c}114 \\
23 \% \\
\end{array}$ & $\begin{array}{l}322 \\
65 \% \\
\end{array}$ & $\begin{array}{c}57 \\
11 \% \\
\end{array}$ & $\begin{array}{c}7 \\
1 \% \\
\end{array}$ & 957 & $1.91 \pm 0.63$ & $\begin{array}{r}329 \\
34 \% \\
\end{array}$ & $\begin{array}{l}628 \\
66 \% \\
\end{array}$ \\
\hline
\end{tabular}

ous species of vertebrates have revealed that a given species may be polymorphic as to the number and sizes of nucleolar organiser regions. This variability may be breed-specific or individual-specific. Furthermore, it can be affected by the usability type, age and physiological condition of the organism (RAŠKA et al. 2006; ANDRASZEK et al. 2010). Additionally, various studies of NOR activity in different species have confirmed that the activity is not uniform in all NOR-chromosomes. It is assumed that the number of pigmented mitotic NORs depends on the rDNA transcription activity. It is assumed that it is those NORs in which transcription will occur in the next cell cycle that become pigmented. This is why not all the nucleolar organiser regions are active at the moment of staining and not all potential NORs become pigmented at the same time (OLSON 2004; RAŠKA et al. 2006). Studies of the activity of nucleolar organiser regions in humans showed that the highest activity is that of the 21st pair of chromosomes (RAŠKA et al. 2006). Experiments performed on cattle revealed the highest frequency in the third largest chromosome containing an active NOR and in the smallest NOR-chromosome (DI BERARDINO et al. 2001).

In the metaphases of the same animal there is an intercellular differentiation of NOR expression in relation to the quantity, magnitude and intensity of silver deposit staining. Homologous chromosomes can be silver-stained in different ways. Meticulous 
experiments confirmed that a chromosome with a longer secondary constriction was more prominently stained, while its homologue was less vivid or unpigmented. Differences in the sizes and number of NORs at the cellular and individual level were also observed in other animal species, such as: cattle, horses, sheep, goats, rabbits, mink and hens (ANDRASZEK \& SMALEC 2007; ANDRASZEK et al. 2009). Moreover, research has shown that the sites of visible NORs correspond with the sites of ribosomal genes identifiable with rDNA probes. Very rarely can these sites be made visible with staining techniques, as part of the rRNA gene copies is below the sensitivity threshold of silver staining (RAŠKA et al. 2006; DELANY et al. 2009).

Based on the results of the present study and information from secondary sources, it can be concluded that the high variability of the numbers and sizes of nucleoli is typical of avian cells. Yet, at the present stage of knowledge this conclusion should be considered hypothetical. The reasons for such variability are unknown, nor is it understood whether they are physiological, oviparity-related or evolutionarily determined.

The nucleolus plays an essential role in mechanisms associated with carcinogenesis, telomerase function control and p53 protein stabilisation (RYAN et al. 2001; RUBBI \& MILNER 2003; HOFMANN et al. 2005). Nucleolar morphology is also affected by epigenetic mechanisms at the level of DNA methylation. rRNA-encoding genes are present in two forms. Their "open" conformation is transcriptionally active, whereas the "closed" conformation is connected with the so-called transcription breakdown. Entire NORs or only some nucleolar organiser genes can be suppressed. This is directly associated with ongoing age-related methylation (GRUMMT \& PIKAARD 2003). The nucleolus is also increasingly more often used in neoplasm diagnostics. Early studies by MONTGOMERY (1895) showed that fast-growing cells have a higher number of nucleoli which are also untypically large. Combined with AgNOR staining, this fact facilitates the diagnostics of excessively proliferating cells. This is of particular importance with throat tumours, breast cancer, prostate cancer, cancer of the urinary system and thyroid carcinoma (CAMARGO et al. 2005; ROMAO-CORREA et al. 2005; MADEJ et al. 2006).

Although the fundamental function of the nucleolus is to control ribosome biogenesis, an interdependence has recently been identified between nucleolar morphology and cellular aging processes. Experiments on yeast cells confirmed that damage to rRNA genes causes the disintegration of nucleoli which itself is a symptom of aging. Pilot studies of domestic horses, concerning the effect of age on nucleolar structures, confirmed the age-related disintegration of nucleoli (ANDRASZEK et al. 2010). This research will be supplemented with analyses of rRNA gene expression and methylation in animals of different ages. Chicken and quail are quickly maturing animals with a fast generational rotation. They can be readily used for cytogenetic experiments concerning aging processes and age-related cellular structure alterations.

\section{References}

ANDRASZEK K., SMALEC E. 2007. Number and size of nucleoli in the spermatocytes of European domestic goose (Anser anser). Arch. Geflügelk. 71: 237-240.

ANDRASZEK K., SMALEC E. 2008. Spermatogenesis process as exemplified by meiosis in European domestic goose ( $A n-$ ser anser). Arch. Geflügelk. 72: 110-15.

ANDRAsZEK K., SMALEC E., CZYŻEWSKA D. 2008. The structure of the synaptonemal complexes in meiocytes of European domestic goose (Anser anser). Folia Biol. (Kraków) 56: 139-147.

AndraszeK K., Horoszewicz E., SMaleC E. 2009a. Nucleolar organizer regions, satellite associations and nucleoli of goat cells (Capra hircus). Arch. Tierz. 52: 177-186.

ANDRASZEK K., SMALEC E., TOKARSKA W. 2009b. Identification and structure of lampbrush sex bivalents prior to and after the reproduction period of the European domestic goose Anser anser. Folia Biol. (Kraków) 57: 143-148.

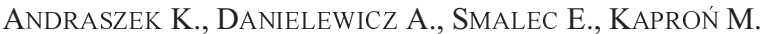
2010. Identification of the nucleoli in domestic horse spermatocytes - preliminary investigations. Rocz. Nauk. PTZ 6: 13-21.

APITZ M., WAGNER K. U., SAAR W. 1995. Karyotype characteristics in domestic ducks and geese. $10^{\text {th }}$ European Symposium on Waterflowl, Halle-Saale, 465-472 pp.

Burt D. W., Bruley C., DunN I. C., Jones C. T., Ramage A., LAW A. S., MORRICE D. R., PATON I. R., SMITH J. WINDSOR D., SAZANOV A., Fries R., WADDIngton D. 1999. The dynamics of chromosome evolution in birds and mammals. Nature 402: 411-413.

CAMARgo R. S., MAEdA M. Y., Di Loreto C., SHIRATA N. K., Anselmo GARCIA E., Filho A. L. 2005. Is AgNOR and DNA ploidy analysis useful for evaluating thyroid neoplasms? Anal. Quant. Cytol. Histol. 27:157-161.

Delany M. E., Muscarella D. E., Bloom S. E. 1991. Formation of nucleolar polymorphisms in trisomic chickens and subsequent microevolution of rRNA gene clusters in diploids. The J. Hered. 82: 213-220.

Delany M. E., Robinson Ch. M., Goto R. M., Miller M. M. 2009. Architecture and organization of chicken microchromosome 16: Order of the NOR, MHC-Y, and MHC-B Subregions. J. Hered. 100: 507-514.

Derenzini M., Pasquinelli G., O’Donohue M. F., PloTON D., THIRY M. 2005. Structural and functional organization of ribosomal genes within the mammalian cell nucleolus. J. Histochem. Cytochem. 54: 131-145.

Di Berardino D., Di MEO G. P., Gallagher D. S., HAYES H., IANNUZZI L. 2001. International System for Chromosome Nomenclature of Domestic Bovids (ISCNDB 2000). Cytogenet. Cell Genet. 92: 283-299.

GRUMMT I., PIKAARD C. S. 2003. Epigenetic silencing of RNA polymerase I transcription. Nature reviews. Mol. Cell Biol. 4: 641-649.

GuTTENBACH M., NANDA I., FEICHTINGER W., MASABANDA J. S., GRIFFIN D. K., SCHMID M. 2003. Comparative Chromosome Painting of Chicken Autosomal Paints 1-9 in Nine Different Bird Species. Cytogenet. Genome Res. 103: 173-184. 
HERNANDEZ-VERDUN D. 2006. Nucleolus: From structure to dynamics. Histochem. Cell Biol. 125: 127-137.

Hofmann M., Eggeling C., JaKobS S., Hell S. W. 2005. Breaking the diVraction barrier in fluorescence microscopy at low light intensities by using reversibly photoswitchable proteins. Proc. Natl. Acad. Sci. USA 102.

Howell W. M., Black D. A. 1980. Controlled silverstaining of nucleolus organizer regions with a protective colloidal developer a 1-step method. Experentia 36: 1014-1015.

ICGSC 2004. Sequence and Comparative Analysis of the Chicken Genome Provide Unique Perspectives on Vertebrate Evolution. Nature 432: 695-716.

LADJALI-MOHAMMEDI K., BITGOOD J. J., TIXIER-BOICHARD M. PONCE DE LEON F. A. 1999. International System for Standardized Avian Karyotypes (ISSAK): Standardized Banded Karyotypes of the Domestic Fowl (Gallus domesticus). Cytogenet. Cell Genet. 86: 271-276.

Lam Y. W., Trinkle-Mulcahy L., Lamond A. L. 2005. The nucleolus. J. Cell Sci. 8: 1335-1337.

Madej P., Plewka A., Madej J. A., Plewka D., RutKOWSKI T. 2006. Nucleolar organizer regions (NORs) in adenomyosis. Pathol. Res. Pract. 202: 433-437.

Masabanda J. S., Burt D. W., O’Brien P. C., Vignal A., FILLON V., WALSH P. S., COX H., TEMPEST H. G., SMITH J., HABERMANN F., Schmid M., MATSUda Y., FERGUSON-Smith M. A., Crooijmans R. P., Groenen M. A., GrifFIN D. K. 2004. Molecular Cytogenetic Definition of the Chicken Genome: The First Complete Avian Karyotype. Genetics 166: 1367-1373.

MCNALLY L. R. 2004. Chromosomal localization of a proinsulin transgene inserted with a transposon-based vector into japanese quail, Coturnix coturnix. PhD, Louisiana State University

Muscarella D. E., Vogt V. M., Bloom S. E. 1985. The ribosomal RNA gene cluster in aneuploid chicken: evidence for increased gene dosage and regulation of gene expression. J. Cell Biol. 101: 1749-1756.

Olson M. O., Hingorani K., SzEBEni A. 2002. Conventional and nonconventional roles of the nucleolus. Int. Rev. Cytol. 219: 199-266.

OLson M. O. 2004. The Nucleolus. Kluwer Academic Plenum Publisher, London.

OSPINA J. K., MATERA A. G. 2002. Proteomics: the nucleolus weighs in. Curr. Biol. 12: 29-31.
Pollock D. L., FeCHHEIMER N. S. 1978. The chromosomes of cockerels (Gallus domesticus) during meiosis. Cytogenet. Cell Genet. 21: 267-281.

PRIETO J. L., MCSTAY B. 2005. Nucleolar biogenesis: the first small steps. Biochem. Soc. Trans. 33: 1441-1443.

RAŠKA I., KOBERNA K., MALinsK J., Fidlerova H., MASATA M. 2004. The nucleolus and transcription of ribosomal genes. Biol. Cell 96: 579-94.

RAŠKA I., SHAW P. J., CMARKO D. 2006. New insights into nucleolar architecture and activity. Int. Rev. Cytol. 255: 177-235.

ROMAO-CORREA R. F., MARIA D. A., SOMA M., SOTTO M. N., SANCHES J. A., NETO C. F., RUIZ I. R. 2005. Nucleolar organizer region staining patterns in paraffin-embedded tissuecells from human skin cancers. J. Cutan. Pathol. 32: 323-328.

RUBBI C. P., MiLnER J. 2003. Disruption of the nucleolus mediates stabilization of $\mathrm{p} 53$ in response to DNA damage and other stresses. EMBO J. 22: 6068-6077.

RYAN K. M., PhILliPS A. C., VOUSDEN K. H. 2001. Regulation and function of the p53 tumor suppressor protein. Curr. Opin. Cell Biol. 13: 332-337.

Schmid M., Nanda I., GutTenbach M., Steinlein C., HoEHn H., Schartl M., HAAF T., Weigend S.,. Fries R., BuerstedDE J. M., WimMERs K., BuRT D. W., SMith J., A'Hara S., LAW A., Griffin D. K., BUMSTEAD N., KaUfMAN J., THOMSON P. A., BURKE T., GROENEN M. A. M., Crooijmans R. P. M. A., Vignal A., Fillon V., MorisSON M., PITEL F., TIXIER-BOICHARD M., LADIALI-MOHAMmedi K., Hillel J., Maki-Tanila A., Cheng H. H., DELANY M. E., BURNSIDE J., MIZUNO S. 2000. First Report on Chicken Genes and Chromosomes 2000. Cytogenet. Cell Genet. 90: 169-218.

Schmid M., Nanda I., Hoehn H., Schartl M., HaAF T., BUERSTEDDE J. M., ARAKAWA H., CALDWELL R. B., WEIGEND S., BURT D. W. SMITH J., GRIFFIN D. K., MASABANDA J. S., GRoEnEn M. A. M., CRoOiJMans R. P. M. A., VIGNAL A., FILLON V., MORISSON M., PITEL F., VIGNOLES M., GARRIGUES A., GELLIN J., RodionOV A. V., GALKINA S. A., Lukina N. A., BEN-ARI G., Blum S., Hillel J., Twito T., LaVi U., David L., FELDMAn M. W., DElany M. E., CONLEY C. A., Fowler V. M., Hedges S. B., Godbout R., KatYal S., SMith C., HudSOn Q., Sinclair A., Mizuno S. 2005. Second Report on Chicken Genes and Chromosomes 2005. Cytogenet. Genome Res. 109: 415-479.

SHAw P. J., JoRDAn E. G. 1995. The nucleolus. Annu. Rev. Cell Dev. Biol. 11: 93-121. 